\title{
Natural killer cells responsiveness to physical exercise: A brief review
}

\author{
Antonio Crisafulli ${ }^{1}$, Filippo Tocco ${ }^{1}$, Franco Melis ${ }^{1}$, Raffaele Milia ${ }^{1}$, Alberto Concu ${ }^{1,2^{*}}$ \\ ${ }^{1}$ Department of Medical Sciences, Research Unit of Sports Physiology, University of Cagliari, Cagliari, Italy; \\ *Corresponding Author: concu@unica.it \\ ${ }^{2} 2 \mathrm{C}$ Technologies Inc., Academic Spin-Off of the University of Cagliari, Cagliari, Italy
}

Received 5 September 2013; revised 5 October 2013; accepted 12 October 2013

Copyright (C) 2013 Antonio Crisafulli et al. This is an open access article distributed under the Creative Commons Attribution License, which permits unrestricted use, distribution, and reproduction in any medium, provided the original work is properly cited. In accordance of the Creative Commons Attribution License all Copyrights (C) 2013 are reserved for SCIRP and the owner of the intellectual property Antonio Crisafulli et al. All Copyright (C) 2013 are guarded by law and by SCIRP as a guardian.

\section{ABSTRACT}

Natural killer cells (NK) are a group of peripheral blood lymphocytes which display cytotoxic activity against a wide range of tumour cells. They are a consistent part of the inflammatory response that is activated when either internal or external injuries occur as they are able to synthesize perforins. An important role is played by NK cells in the host defence against tumours without expressing any antigen-binding recaptor in their membrane which, however, distinguish T and B lymphocytes. NK activity appears early in the immune response, thus providing immediate protection during the time required for the activation and proliferation of cytotoxic $T$ lymphocytes and for their differentiation into functional cells. Even though much research regarding the effects of aerobic training exercise on NK cell numbers and function, there appears to be much controversy regarding its effect. NK cells are rapidly mobilized into circulation in response to acute exercise, most likely by increased shear stress and catecholamine-induced down-regulation of adhesion molecule expression. However, tissue injury and inflammation which often accompanies strenuous exercise have been associated to post-exercise NK cell suppression. Scientific evidence indicates exercise-induced changes in NK cell redistribution and function should be strongly influenced by stress hormones including catecholamines, cortisol and prolactin as well as by soluble mediators such as cytokines and prostaglandins. The role of exercise therapy in cancer patients and survivors rehabilitation is becoming in- creasingly important as it is thought to modulate immunity and inflammation. However, more knowledge about the effects of exercise on immune function in these patients is needed.

Keywords: NK Cells; Aerobic Exercise; Anaerobic Exercise; Catecholamines; Prolactin

\section{INTRODUCTION}

Natural killer cells (NK) were first described in the $1970 \mathrm{~s}$ as a group of peripheral blood lymphocytes (5\% $10 \%$ which display cytotoxic activity against a wide range of tumour cells [1]. Thus, NK cells can be considered as part of the inflammatory response that is activated when either internal or external occur, since they are able to synthesize perforins [2], a family of poreforming proteins of six esterases called granzymes A-F. NK cells play an important role in the host defence against tumours without expressing any antigen-receptor in their membrane which, however, distinguish $\mathrm{T}$ and $\mathrm{B}$ lymphocytes (i.e. the CD3 receptors). Therefore, NK cells lack the attribute of immunologic specificity and memory. The cytolytic activity of NK cells is enhanced by interferon (IFN)-gamma [3] and IL-2 [4,5] whereas prostaglandin E-2 down-regulates the function of NK cells [6]. In humans, Chédiak-Higashi syndrome is associated with an absence of NK cells [7] and an increased incidence of lymphomas. NK cells are also able to lyse some virus-infected target cells [8]. In fact, this NK activity appears early in the immune response, thus providing immediate protection during the time required for the activation and proliferation of cytotoxic $\mathrm{T}$ lymphocytes and for their differentiation into functional cells. A case study has been described in which a young woman lacking NK cells suffered a life-threatening infection 
with cytomegalovirus [9]. NK cells express the p75 kD component of the IL-2 receptor. The IL-2 molecules enable activated NK cells to progress from G1- phase into the proliferative phase of the cell cycle. These cytokines stimulate antiviral activity in IL-2 activated NK cells, and this activation plays an important role in host defence during the first few days of many viral infections until a specific cytotoxic lymphocyte cell response develops. Human NK cells can be subdivided into different populations based on the relative expression of the surface markers CD16 and CD56. The two major subsets are CD56 (bright) CD16 (dim/) (-) and CD56 (dim) CD16 (+), respectively. The CD56 (bright) NK cells are numerically in the minority in peripheral blood but constitute the majority of NK cells in secondary lymphoid tissues. They are abundant cytokine producers but are only weakly cytotoxic before activation. Recent [10] data suggest that under certain conditions, they possess immunoregulatory properties, and that they are probably immediate precursors of CD56 (dim) NK cells. CD56 (bright) NK cell percentages are expanded or reduced in a certain number of diseases, but the significance of these variations is not yet clear. The cytotoxic activity of CD56 (dim) NK cells is significantly higher than that of CD56 (bright) cells and they contain much more perforin, granzymes and cytolytic granules [11]. The high expression level of CD16 makes them efficient mediators of antibody-dependent cellular cytotoxicity, whereas CD56 (bright) CD16 (dim) NK cells perform antibody-dependent cellular cytotoxicity only weakly and CD56 (bright) CD16-NK cells of course not at all [12]. Upon stimulation with cytokines such as IL-2 or IL-12, the cytotoxic activity of all NK cell subsets dramatically increases [13].

\section{IMMUNE FUNCTION AND PHYSICAL EXERCISE}

\subsection{Generalities}

Experimental and clinical evidence indicates that high intensity, long duration physical training is associated with adverse effects on immune function [14,15]. On the contrary, it has been proposed [16] that training schedules with moderate exercise may lower the risk of upper respiratory tract infection (URTI). As pointed out in the "Position statement Part one: Immune function and exercise", by Walsh et al. [17], the hypothesis of a Ushaped relationship between physical activity and resistance to disease makes intuitive sense, in accordance with the general belief that although regular, moderate doses of physical activity have beneficial effects on health, excessive amounts or intensities of physical activity have negative consequences. In the case of the immune system, Shek and Shephard [18] suggested that an excess of physical activity could induce an analogous to clinical sepsis, with tissue destruction from an excessive inflammatory reaction. Although initially conceived simply in the context of URTI [19], the concept of a U-shaped response has now been extended to cover the effects of physical activity upon a variety of clinical disturbances of immune function. In terms of cancer prevention and therapy, Thune and Furberg [20] utilized the metabolic exercise training $\left(\mathrm{MET}=3.5 \mathrm{ml} \mathrm{O}_{2}\right.$ per $\mathrm{kg}$ body weight per min) to estimate the energy cost of physical activities and suggested moderate activity $(>4.5$ MET) more than light activities $(<4.5$ MET) as a good physical activity to protect against overall cancer risk. Moreover, Mooren et al. [21] found that excessive exercise could cause apoptosis and Neubauer et al. [22] showed DNA damage in the same exercise condition. Certain autoimmune conditions also respond to carefully regulated physical activity programmes. In fact, Baslund et al. [23] showed a good effect of 8 wks of bicycle training on the immune system of patients with rheumatoid arthritis, although they pointed out that it would need to be clearly established whether benefit occurs through direct modulation of cell counts and cytokines, or through changes in the activity of transcription factors for pro-inflammatory cytokines. In general, increased levels of $\mathrm{T}$ and $\mathrm{B}$ lymphocyte subclasses have been found during acute exercise [14,24,25], while controversial data have been obtained in the activity of NK cells since they have been found to increase during exercise [26], subsequently decreasing at the end of the effort [27], remain unchanged [28,29], or be reduced [30]. A metaanalysis of 94 studies evaluating NK cell counts showed that there is a marked increase at the end of exercise, and a catecholamin-mediated demargination of cells has been considered as being responsible for this occurrence [31]. However, post-exercise down regulation in $\mathrm{NK}$ cell numbers and activity was seen frequently and this was attributed either to monocyte/granulocyte-induced rises in plasma prostaglandins and/or to cortisol and prolactin increasing blood levels.

\subsection{NK Cells Responsiveness to Prolonged Exercise}

Despite much research regarding the effects of exercise aerobic training on $\mathrm{NK}$ cell numbers and function [17], there appears to be much controversy regarding its effect. Fairey et al. [32] found increased natural killer cell cytotoxic (NKCC) activity with respect to non training subjects in a large trial (25 females) of postmenopausal breast cancer survivors who trained on a cycle ergometer three times per week for 15 wks. On the contrary, Campbell et al. [33] investigated the effect of 12-month aerobic exercise, relative to stretching control, 
on in vitro immune function in a randomized, controlled trial of 115 post-menopausal, overweight, or obese sedentary women demonstrating that NKCC activity did not differ between groups. Hence, they concluded that the controlled trial showed no effect of aerobic exercise on in vitro immune function, despite excellent retention, high adherence, and demonstrable efficacy of the exercise intervention. However, intense training has been shown to alter NK cell subsets and reduce NKCC [34,35]. Despite studies in animals having demonstrated that regular exercise can increase in vivo NK cell cytotoxicity $[36,37]$, it has been found that the specific contribution of these cells in mediating this exercise effect is still unclear [38].

\subsection{NK Cells Responsiveness to Acute Exercise}

There are many papers concerning the acute effects of exercise on circulating NK (CD3- CD16+ CD56+) cells, and this due to their ease of study and large magnitude change in response to exercise [17]. NK cells are rapidly mobilized into the circulation in response to acute exercise, most likely by increased shear stress and catecholamine-induced down-regulation of adhesion molecule expression [39]. Hoffman-Goetz [40] found that during a few minutes of intense exercise the number of NK cells in peripheral blood results increased, and Shephard and Shek showed that the intensity rather than the duration of exercise was responsible for the rise in cell numbers [31]. As shown in a study by Gannon et al. [41], NK cell cytotoxicity is a major functional measure of NK activity. They demonstrated that unstimulated NKCC was dependent on the intensity and duration of the exercise bout since, immediately after a single bout of moderate or exhaustive exercise, there is a $50 \%$ $100 \%$ increase in human peripheral blood NKCC, and this concerns both young and old people [42]. The exercise-induced increase in NKCC is largely due to an increase in the absolute number and percentage of blood NK cells. However, NKCC expressed on a per cell basis does not appear to change much after acute exercise unless the bout is intense and prolonged, in which case NKCC can be depressed for several hours, possibly indicating an enhanced period of susceptibility to infection [43]. There appears to be a differential mobilization such that CD56 (bright) NK cells are less sponsive than CD56 (dim) [17]. This might indicate a reduced ability to defend against pathogens during acute exercise, as CD56 (bright) cells are more cytotoxic. However, the health significance of exercise induced changes in circulating NK cell subsets, like other leukocytes, has not been completely clarified [39]. Concerning the extent to which short-lasting, high-intensity exercise alters NK cell sub- sets, Suzui and colleagues [44] reported on the effects of brief, incremental exercise on these cell subsets. Nine males exercised on a cycle ergometer for $5 \mathrm{~min}$ at each of 4 increasing intensities $(50 \%, 90 \%, 120 \%$, and $140 \%$ of their individual ventilatory threshold), with blood samples drawn after every workload. The authors found that only the proportion of CD56 (dim) cells increased in response to exercise; the proportion of CD56 (bright) cells in the peripheral circulation did not change. However, because of an overall leukocytosis both CD56 (bright) and CD56 (dim) cell counts increased with increasing exercise intensity. In a successive study [45] the same authors confirmed their earlier findings by showing that in 6 males cycling for $30 \mathrm{~min}$ at $120 \%$ of their individual ventilatory threshold $\left(\sim 70 \% \mathrm{VO}_{2 \max }\right)$ the proportion of CD56 (dim) cells, but not the proportion of CD56 (bright) cells, increased significantly. Based on these two studies, one can conclude that the redistribution of CD56 (bright) cells appears to be resistant to changes in exercise intensity. Almost all the experiments in which the behaviour of lymphocyte subclasses was observed during acute exercise concerned prolonged (60 min or more), sub-maximal muscle effort [46-48]. On the other hand, a significant increase in NK cells was seen about sixteen minutes after a head-up tilt test [49] and only about three minutes after the beginning of a physical exercise or a time delay from the evoking stimuli that is too short [50]. However, it could be of interest to understand the relationships among relative levels of reached work rates at each step of an incremental exercise, and the corresponding changes in both absolute NK cell quantity and NK cell percentage in the peripheral blood. The experiment by Del Giacco et al. [51] provides much information on the above requirement. They evaluated the time course of NK cell numbers and relative concentration in peripheral blood at three points: pre-exercise, work-rate corresponding to oxygen consumption at anaerobic threshold $\left(\mathrm{VO}_{2-\mathrm{AT}}\right)$, work-rate at maximum oxygen consumption $\left(\mathrm{VO}_{2 \text {-max }}\right)$, in 8 healthy male subjects who performed a progressive cycle ergometer exercise up to exhaustion. It was observed that while $\mathrm{VO}_{2}$ progressively increased up to $\mathrm{VO}_{2-\max }$, which was $28 \%$ higher than at the $\mathrm{VO}_{2-\mathrm{AT}}$, both $\mathrm{NK}$ cell numbers and relative concentration also increased progressively to reach the workrate corresponding to $\mathrm{VO}_{2-\mathrm{AT}}$, but when the work-rate increased further up to its maximum, in correspondence of $\mathrm{VO}_{2-\max }$, the increases of absolute and relative $\mathrm{NK}$ cell values were only $9 \%$ or a non-statistically significant variation. They concluded that when the contribution from anaerobic sources for exercising muscles became relevant (i.e. in correspondence of $\mathrm{VO}_{2-\mathrm{AT}}$ ) and progressively increased to reach the maximum workload, NK cells ceased to increase. A mismatch between the pro- 
gressively increasing physical stress, occurring from $\mathrm{VO}_{2-\mathrm{AT}}$ to $\mathrm{VO}_{2-\max }$, and the corresponding NK-dependent defence against micro-organisms should have happened when the exercise work rate overcame that corresponding to the $\mathrm{VO}_{2-\mathrm{AT}}[15,31]$. In the same study, to better investigate a possible inhibitory effect of supra-maximal exercise on the exercise-induced NK cells proliferation, Del Giacco and colleagues supposed that if the heavy exercise, whose strength was indicated by the value of the excess in the expired carbon dioxide $\left(\mathrm{CO}_{2-\mathrm{exc}}\right)$ [52], induced NK cell suppression, then the increase in the percentage of these cells at $\mathrm{VO}_{2-\max }$, with respect to $\mathrm{VO}_{2-\mathrm{AT}}$, ought to be as lower as the higher was $\mathrm{CO}_{2 \text {-exc }}$. To verify this hypothesis they tested the following general equation for a quadratic regression:

$$
\mathrm{NK}=a+b \mathrm{CO}_{2-\mathrm{exc}}+c \mathrm{CO}_{2-\mathrm{exc}}^{2}
$$

where NK, which was expressed, in turn, as absolute $\left(\mathrm{mm}^{3}\right)$ or percentage $(\%)$ values, represents the difference of these cell values at $\mathrm{VO}_{2-\max }$ and at $\mathrm{VO}_{2-\mathrm{AT}}$, respectively. Applying the Eq. (1) to their data, del Giacco et al. obtained parabolas with parameter $(b)$ which was a negative number and parameter $(c)$ which was a positive number, or by one arm descending followed by the other arm ascending. This means that the higher the $\mathrm{CO}_{2 \text {-exc }}$ at the end of the progressive exercise the lower the increase of the NK cells concentration at this point with respect to the value observed at $\mathrm{VO}_{2 \text {-AT. }}$. However, when $\mathrm{CO}_{2 \text {-exc }}$ reached at $\mathrm{VO}_{2-\max }$ was very high, the direction of this relationship was inverted. The authors concluded that the $\mathrm{CO}_{2 \text {-exc }}$ value corresponding to the parabolas vertex marks the transition at which NK cell inhibitory mechanisms stopped their prevalence on activator mechanisms. It must be considered that tissue injury and inflammation which often accompanies strenuous exercise have been associated to post-exercise NK cell suppression [53]. However, since it has been found that certain indices of oxidative damage to skeletal muscle appeared only at the end of heavy exercise $[54,55]$, it may be that a precocious down regulation of NK cells, due to these exercise induced muscle injuries, should be reached before the cessation of a strenuous, anaerobic exercise when lactate flow from the working muscles to blood becomes consistent (i.e. $\mathrm{CO}_{2 \text {-exc }}$ increases). If this happens, an unprotected window, lasting the time in which the subject works over the anaerobic threshold, ought to be opened during which the athlete becomes susceptible to viral infections.

\section{ENDOCRINE CONTROL OF NK CELLS ACTIVITY DURING EXERCISE}

\subsection{Generalities}

Responses to stressful events, as is the physical exer- cise performed at work rates up the anaerobic threshold, are generally regarded as reactions of the organism to accommodate to or compensate for stress. This reaction is classically described as an activation of the symphato-adrenal system and the hypothalamic-pituitaryadrenocortical axis. Recently, in men who cycled at 40 , 60,80 and $100 \%$ of their power output at $\mathrm{VO}_{2 \max }$ in successive time blocks of 10 minutes each up to exhaustion, De Vries et al. [56] showed that increases in cathecolamines reflected the relative work load, increases in prolactin occurred only after exercise reached an intensity of $80 \% \mathrm{VO}_{2 \max }$ whereas increases in cortisol were found just after exhaustion. These results suggest that activation of stress hormones occurs at different time points, supporting the notion that these hormones have different roles in preparing the organism for physical activity and recovery, i.e. workload-related adaptation on the one hand and protection against disturbed homeostasis and leukocytes redistribution in the circulation on the other. When physical exercise reaches a workload exceeding that corresponding to the anaerobic threshold, it typically results in muscle soreness and injury, and inflammatory response to the muscle injury is initiated, characterized by the movement of fluid, plasma proteins, and leukocytes, including NK cells, into the injured area [46]. An exaggerated response in the inflammatory cascade, which could compromise the actual request of mechanical work from exercising muscles, is prevented via several pathways including the activation of the hypothalamic-pituitary system which exerts a strong antiinflammatory action [57]. Nevertheless, if anaerobic stress becomes too high, i.e. the $\mathrm{CO}_{2 \text { exc }}$ at $\mathrm{VO}_{2-\max }$ reaches very high values, NK cell concentration achieved at the maximum work-rate could tend to slow its descent with respect to the $\mathrm{VO}_{2-\mathrm{AT}}$ value and, in agreement to the Eq. (1), it starts to increase again [17]. In light of the opposite pro-inflammatory/anti-inflammatory mechanisms which take place when strenuous exercise is performed, such a pro-inflammatory/protective mechanism against infection could gradually prevail against the antiinflammatory/performance-preserving mechanism when the subject's anaerobic power becomes too high. A lot of scientific evidence indicates exercise-induced changes in NK cell redistribution and function ought to be strongly influenced by stress hormones including catecholamines, cortisol and prolactin as well as by soluble mediators such as cytokines and prostaglandins.

\subsection{Catecholamines}

Catecholamine effects on NK cell activity and redistribution have been extensively studied [36,58-60], and it has been found that NK cells express both adrenergic beta- 1 and beta- 2 receptors in their membrane [61]. 
However, mainly beta 2 subtype are found on the membrane of these cells [36,59]. Klokker et al. [60] found that both beta 1 and beta 2 adrenergic receptor blockade suppress NK cell increase due to head-up tilt. The effects of catecholamines could include the recruitment of NK cells from the spleen or other sites to the circulating pool due to the reduced adhesion of NK cells to endothelial cells $[36,62]$. In fact, local infiltration of epinephrine to reduce bleeding in patients undergoing a surgical intervention under general anaesthesia produced an instantaneous increase in both NK cell circulating number and activity [63]. In rats The number of blood NK cells doubled within 10 min of metaproterenol administration and returned to baseline levels within $1 \mathrm{~h}$. By this time, metaproterenol suppressed blood NK activity in a dosedependent manner. Two beta-adrenergic antagonists, propranolol, which crosses the blood-brain barrier, and nadolol, which does not, blocked this suppression [64]. Considering humans, plasma catecholamines were determined in peripheral blood of subjects resting in supine position by Knudsen et al. [65] and a negative correlation was found between epinephrine and the percentage of CD3-CD56+ cells. The Authors suggested that epinephrine plays a dual effect on NK cells: an acute effect by which NK cells are mobilised from depots and a chronic effect which reduced the number of these cells in peripheral blood. The same conclusion was supported by the observations reported by Nagao et al. [62] who suggested that moderate exercise induced a mobilisation of NK cells in men due to down-modulation of NK cell surface adhesion molecules by catecholamines but, in contrast to this, NK cells rapidly decreased below base level after the exercise. Moreover, the increase in epinephrine due to $60 \mathrm{~min}$ of bicycle ergometer at $75 \%$ of $\mathrm{VO}_{2 \max }$ and the increase in epinephrine in the same subjects due to its infusion up to reach plasma concentrations comparable with those seen during exercise, induced a comparable increase in NK $(\mathrm{CD} 16+)$ cells concentration in the peripheral blood which, however, dropped below basal levels $2 \mathrm{~h}$ afterward. Even though a positive relationship between an exercise induced increase in NK cell numbers and activity and corresponding rises in blood catecholamines seems to be demonstrated [62,66,67], Mackinnon [26] pointed out that the effects of exercise-dependent increasing blood catecholamines on NK cells number and concentration depend on differences in muscle group activation, intensity and duration of exercise. In fact, in subjects of the above experiment, $60 \mathrm{~min}$ bicycle exercise at $80 \%$ of the $\mathrm{VO}_{2 \max }$ induced a significantly higher increase in catecholamines and in peripheral blood NK cells than $60 \mathrm{~min}$ back-muscle training up to $29 \%$ of $\mathrm{V}_{\mathrm{O} 2 \max }$. Both moderate exercise (45 min at $60 \% \mathrm{~V}_{02 \max }$ ) in women and intense exercise $\left(80 \% \mathrm{~V}_{\mathrm{O} 2 \max }\right.$ up to exhaustion) in men showed a workload related increase in NK cells associated with a correspondingly high increase in plasma catecholamines [67]. All the above mentioned observations suggest a catecholamine-dependent increase in both concentration and percentage of NK cells when workload increases progressively up to reach the $\mathrm{VO}_{2-\mathrm{AT}}$. However, despite catecolamines still increase up to reach $\mathrm{VO}_{2-\max }$, it has been found that NK cells ceases to increase further [51]. To explain this fact, some other changes occurring in hormone plasma levels and soluble mediators, when anaerobic mechanisms are recruited, must be considered. Prostaglandin E2 (PGE2), Cortisol and prolactin are all known for their inhibitory action on exercise-induced increases in NK cell numbers and activity, and each of them might be a candidate to play such a role in the anaerobic-dependent smoothing of the NK versus workload relationship.

\subsection{Prostaglandins}

Much evidence supports a marked effect of PGE2 on NK cell biology [68]. Recent research [69] has reported that NK cells express all PGE2 EP receptors and that PGE2 acts on NK cells through the EP2 and/or EP4 receptor subtypes, which are known to be powerful activetors of the adenylate cyclase system. The adenylate cyclase system is involved in inhibiting killing by NK cells and inducing the CD94/NKG2A inhibitory NK receptor following PGE2 signaling [70], and for this PGE2 has an inhibitory effect on NK cell function. It can be deduced that the EP2/EP4 receptors have emerged as pivotal regulators of NK cell activity, and targeting these recaptors may prevent NK inhibition by PGE2. Recently, Uchida et al. [71] compared four different intensities of a bench press exercise for PGE2 concentrations in the blood of 35 healthy men. They found that, with respect to non exercising subjects, Serum PGE2 concentration increased markedly $(\mathrm{P}<0.05)$ after exercise consisting in a workload of $100 \%$ of maximum. These observations support the possibility that PGE2 could well explicate their inhibitory activity on NK cells when physical exercise reaches very high workloads.

\subsection{Cortisol}

It is well known that sustained exercise induces an increase in blood cortisol levels, and Gatti et al. [72] showed that, in vitro, pre-incubation for $20 \mathrm{~h}$ of peripheral blood monuclear cells with $1 \times 10^{-8}$ to $1 \times 10^{-5}$ cortisol resulted in a significant decrease of NK cell activity. However, It has been observed that cortisol begins to accumulate in the blood after a delay of several minutes from the start of exercise and it peaks at a large stage during exercise or shortly afterwards, depending on the type and intensity of activity that is undertaken [56]. 
During acute time-limited exercise stress, as is an incremental exercise up to exhaustion, previous experiments showed that blood cortisol did not increase [25,56] or increased slightly as it is unlikely that such a modest increment alone can account for the magnitude of the exercise induced relative immunodepression [14] shown when workload passes from $\mathrm{VO}_{2-\mathrm{AT}}$ to $\mathrm{VO}_{2 \text {-max }}$. Singh et al. [73], before a high-intensity exercise, randomly gave dexamethasone, hydrocortisone and placebo to healthy subjects and immediately after the exercise they observed that increases in CD56 lymphocyte subsets were comparable in all three conditions. This observation concords with an exclusion of such an inhibitory role of endogenous corticosteroids in the lack of NK cell increase when the anaerobic threshold has been overcome during an incremental exercise. Furthermore, during the course of $4 \mathrm{~h}$ immobilization stress in pigs, a negative correlation between blood cortisol and NK cell citotossicity was seen only at the late phase of the stress [74]. It is possible that the delayed cortisol response to exercise stress may be initiated by a drop in blood glucose levels as well as against tissue damage due to vigorous and prolonged muscular effort [56].

\subsection{Prolactin}

De Meirleir et al. [75] and Luger et al. [76] showed that subjects exercising at a workload lower than that corresponding to their anaerobic threshold did not increase their plasma prolactin levels, but this hormone rose promptly and significantly in the plasma when workload reached and overcame anaerobic threshold. On the other hand, Melis et al. [77], in elite windsurfers simulating windsurfing movements with a specific laboratory ergometer, found that after 30 min of heavy exercise blood levels of prolactin were significantly reduced. These authors interpreted their results as being due to a gratifying response of the mesolimbic, dopaminergic neurons which project their axons, in an inhibitory way, on hypothalamic neurons controlling prolactin-releasing pathways. These athletes also reported to have not reached any sensation of fatigue during the test, and this concords with the idea that to increase plasma levels of prolactin such psycho-physical stressors are need. Chambers et al. [78] were able to identify in rat NK cells the expression of receptors for prolactin by a combination of reverse transcription/polymerase chain reaction and Southern blotting. Moreover, subjects with pathological hyperprolactinemia showed a reduced function of NK cells which was reversed by bromocriptine treatment, and a prolactin-induced low active binding to target cells together with a reduction in active killing and recycling capacity in NK cells was proposed [79]. It has been found that when exercise workload overcame $\mathrm{VO}_{2-\mathrm{AT}}$ the increase in blood lactate may coincide with a wide increase in blood prolactin levels [76]. This, in turn, may interact with NK cell surface receptors for prolactin limiting further increases in NK cell count in the peripheral blood. An exaggerated response in the inflammatory cascade, which might compromise the actual request of mechanical work from exercising muscles, could be prevented via the activation of the hypothalamic-pituitary system from which prolactin can be released into the blood. Prolactin, in turn, may reduce NK cell contribution in the inflammatory response to strenuous exercise, thus contributing to maintain the highest work output from recruited muscles.

\section{NK CELLS AND PRO-INFLAMATORYI ANTI-INFLAMATORY ADVERSE ME-CHA NISMS}

Although many previous findings [12,14,15,80-83] support the increase in circulating NK cell count during progressive exercise as well as the rapid post-exercise NK cell recovery, however, the experiment by Del Giacco et al. [51] showed that the number of NK cells at the maximum workload did not further increase with respect to their number counted at $\mathrm{VO}_{2-\mathrm{AT}}$. This fact probably meant that when the contribution from anaerobic sources for exercising muscles became relevant (i.e. in correspondence of the $\mathrm{VO}_{2-\mathrm{AT}}$ ) and progressively increased up to reach the maximum workload, NK cells ceased to increase. A mismatch between the progressively increasing physical stress, occurring from $\mathrm{VO}_{2-\mathrm{AT}}$ to $\mathrm{VO}_{2 \text {-max }}$, and the corresponding NK-dependent defence against micro-organisms $[15,84]$ should have happened when exercise work rate overcame the $\mathrm{VO}_{2-\mathrm{AT}}$ and progressively approached the $\mathrm{VO}_{2-\max }$. Interestingly, the applied regression analyses in the experiments of Del Giacco et al. [51] indicate that when the value of NK cell count at $\mathrm{VO}_{2 \text {-max }}$ was subtracted from that at $\mathrm{VO}_{2-\mathrm{AT}}$, the lower the difference was, the higher the corresponding excess of carbon dioxide in the expired air $\left(\mathrm{CO}_{2 \text {-exc }}\right)$ was. Considering that recent experiments have confirmed that the higher $\mathrm{CO}_{2 \mathrm{exc}}$ is the higher the rate of lactate production in the blood is [85], thus a higher engagement in the lactate metabolism could induce a greater limitation to an increase in the NK cell concentration and percentage in the peripheral blood leukocytes. The above considerations suggest that a progressively higher lactate metabolism involvement could induce a limitation to further increase the NK cell count and their relative percentage in peripheral blood leukocytes. However, data from the Eq. (1) concerning the quadratic regression obtained by Del Giacco et al. [51] suggested that this trend could be reversed in correspondence of very high $\mathrm{CO}_{2 \text {-exc }}$ values (i.e. values overcoming those corresponding to the 
parabola vertex). This aspect agrees with the possibility that a pinpoint threshold for $\mathrm{CO}_{2-\mathrm{exc}}$ should occur, above which a shift from inhibition to activation of NK cells activity is induced. In the light of the pro-inflammatory/anti-inflammatory adverse mechanisms which take place when a strenuous exercise is being performed, such a pro-inflammatory/protective mechanism against infection tends to progressively recover with respect to the anti-inflammatory/performance-preserving mechanism. Nevertheless, this hypothesis must be confirmed by further experiments in which NK cell numbers and percentage in the peripheral blood reached at critical time points in subjects working over the anaerobic threshold, as are those comprised between $\mathrm{VO}_{2-\mathrm{AT}}$ and $\mathrm{VO}_{2-\max }$, are compared with corresponding blood levels of prolactin, cortisol, catecholamines and prostaglandin E-2.

\section{NK CELLS, EXERCISE AND TUMOURS}

Translating all the above considerations on possible interactions among NK cells, physical exercise and tumour proliferation/inhibition, a recent and very important study by Inbar et al. [86] on rats, to which a dose of CRNK-16 leukemia cells was administered, showed that when they were subjected to intermittent forced swim stress mortality rates were increased. However, prolonged $\beta$-adrenergic blockade increased baseline survival rates possibly by blocking tumour-related levels of catecholamines and prostaglandins. The authors found that the physical stressor transiently suppressed NK activity against CRNK-16 lines on a per NK basis. They concluded that environmental stress, like strenuous exercise, promoted leukemia progression in rats, potentially through suppressing the cell mediated immunity mainly played by NK cells. The role of exercise therapy in the rehabilitation of cancer patients and survivors is becoming increasingly important as it is thought to modulate immunity and inflammation. However, more knowledge about the effects of exercise on immune function in these patients is needed. A systemic review was recently carried out by Kruijsen-Jaarsma et al. [86] and they found that various immune parameters improved after exercise. However, knowledge of the effects of exercise on immune function in cancer patients is still limited. In this systematic review, the authors found that natural killer cytotoxic activity increased after exercise in cancer patients, along with lymphocyte proliferation and granulocyte cell counts. The number of leukocytes, lymphocytes, natural killer cells, T lymphocytes, C-reactive protein, and pro- and anti-inflammatory mediators remained stable in response to exercise. In agreement with KruijsenJaarsma et al., it can be concluded that additional research is needed to gain insight into the mechanism linking exercise and immune function of NK cells in different populations, as well as to better understand the association between this immune parameter and clinical outcomes.

\section{ACKNOWLEDGEMENTS}

We would like to thank Mr Barry Mark Wheaton for his editorial assistance.

\section{REFERENCES}

[1] O'Shea, J. and Ortado, J.R. (1992) The biology of the natural killer cells: Insights into the molecular basis of function. In: Lewis, C.E. and McGee, J.O. Eds., The Natural Killer Cell, Oxford University Press, Oxford, 1-40.

[2] Zhou, J., Olsen, S., Moldovan, J., Fu, X., Sarkar, F.H., Moudgil, V.K. and Callewaert, D.M. (1997) Glucocorticoid regulation of natural cytoxicity: Effects of cortisol on the phenotype and function of a cloned human natural killer cell line. Cellular Immunology, 178, 108-116. http://dx.doi.org/10.1006/cimm.1997.1138

[3] Ortado, J.R., Mantovani, A., Hobbs, D., Rubinstein, M., Pestka, S. and Herberman, R.B. (1983) Effects of several species of human leukocyte interferon on cytotoxic activity of NK cells and monocytes. International Journal of Cancer, 31, 285-289. http://dx.doi.org/10.1002/ijc.2910310306

[4] Matera, L. and Mori, M. (2000) Cooperation of pituitary hormonr prolactin with interleukin-2 and interleukin-12 on production of interferon-gamma by natural killer and T cells. Annals of the New York Academy of Sciences, 917, 505-513.

http://dx.doi.org/10.1111/j.1749-6632.2000.tb05415.x

[5] Nielsen, H.B. and Pedersen, B.H. (1997) Lymphocyte proliferation in response to exercise. European Journal of Applied Physiology and Occupational Physiology, 75, 375-379. http://dx.doi.org/10.1007/s004210050175

[6] Rhind, S.G., Gannon, G.A., Suzui, M., Shephard, R.J. and Shek, P.N. (1999) Indomethacin inhibits circulating $\mathrm{PGE}_{2}$ and reverses postexercise suppression of natural killer cell activity. American Journal of Physiology, 276, R1496-R1505.

[7] Barak, Y. and Nir, E. (1987) Chediak-Higashi syndrome. American Journal of Pediatric Hematology/Oncology, 9, 42-55.

[8] Welsh, R.M. and Vargas-Cortes, R.M. (1992) Natural killer cells in viral infection. In: Lewis, C.E. and McGee, J.O. Eds., The Natural Killer Cell, Oxford University Press, Oxford, 108-150.

[9] Kuby, J. (1992) Immunology. WH Freeman and Co., New York, 304-306.

[10] Poli, A., Michel, T.M., Andrès, E., Hentges, F. and Zimmer, J. (2009) CD56 bright natural killer (NK) cells: An important NK cell subset. Immunology, 4, 458-465. http://dx.doi.org/10.1111/j.1365-2567.2008.03027.x

[11] Jacobs, R., Hintzen, G., Kemper, A., Beul, K., Kempf, S., Behrens, G., Sykora, K.W. and Schmidt, R.E. (2001) 
CD56 ${ }^{\text {bright }} \mathrm{NK}$ cells differ in their KIR repertoire and cytotoxic features from CD56 ${ }^{\mathrm{dim}} \mathrm{NK}$ cells. European Journal of Immunology, 31, 3121-3126. http://dx.doi.org/10.1002/1521-4141(2001010)31:10<312 1::AID-IMMU3121>3.0.CO;2-4

[12] Cooper, M.A., Fehniger, T.A. and Caligiuri, M.A. (2001) The biology of human natural killer-cell subsets. Trends in Immunology, 22, 633-640. http://dx.doi.org/10.1016/S1471-4906(01)02060-9

[13] Nagler, A., Lanier, L.L., Cwirla, S. and Phillips, J.H. (1989) Comparative studies of human FcRIII-positive and negative natural killer cells. The Journal of Immunology, 143, 3183-3191.

[14] Hoffman-Goetz, L. and Pedersen, B.K. (1994) Exercise and the immune system: A model of the stress response? Immunology Today, 15, 282-287. http://dx.doi.org/10.1016/0167-5699(94)90177-5

[15] Del Giacco, S.R., Manconi, P.E. and Del Giacco, G.S. (2001) Allergy and sports. Allergy, 56, 215-223. http://dx.doi.org/10.1034/j.1398-9995.2001.056003215.x

[16] Nieman, D.C. (1994) Exercise, infection, and immunity. International Journal of Sports Medicine, 15, S131-S141. http://dx.doi.org/10.1055/s-2007-1021128

[17] Walsh, N.P., Gleeson, M., Shephard, R.J. et al. (2011) Position statement, Part one: Immune function and exercise. Exercise Immunology Review, 17, 6-63.

[18] Shek, P.N. and Shephard, R.J. (1998) Physical exercise as a human model of limited inflammatory response. Canadian Journal of Physiology and Pharmacology, 76, 589-597. http://dx.doi.org/10.1139/y98-040

[19] Nieman, D.C. and Nehlsen-Cannarella, S.L. (1992) Exercise and Infection. In: Watson, R.R., Eisinger, M. and Boca Raton, F.L., Eds., Exercise and Disease, CRC Publishers, New York, 121-148.

[20] Thune, I. and Furberg, A.S. (2001) Physical activity and cancer risk: Dose-response and cancer, all sites and site-specific. Medicine \& Science in Sports \& Exercise, 33, S530-S550.

[21] Mooren, F.C., Lechtermann, A. and Volker, K. (2004) Exercise-induced apoptosis of lymphocytes depends on training status. Medicine \& Science in Sports \& Exercise, 36, 1476-1483.

http://dx.doi.org/10.1249/01.MSS.0000139897.34521.E9

[22] Neubauer, O., Reichhold, S., Nersesyan, A., Koenig, D. and Wagner, K.H. (2008) Exercise induced DNA damage: Is there a relationship with inflammatory responses? Exercise Immunology Review, 14, 51-72.

[23] Baslund, B., Lyngberg, K., Andersen, V., Halkjaer, K.J., Hansen, M., Klokker, M. and Pedersen B.K. (1993) Effect of $8 \mathrm{wk}$ of bicycle training on the immune system of patients with rheumatoid arthritis. Journal of Applied Physiology, 75, 1691-1695.

[24] Shinkai, S., Shore, S., Shek, P.N. and Shephard, R.J. (1992) Acute exercise and immune function. Relationship between lymphocyte activity and changes in subset counts. International Journal of Sports Medicine, 13, 452-461. http://dx.doi.org/10.1055/s-2007-1021297

[25] Van Der Pompe, G., Bernards, N., Kavelaars, A. and Hei- jnen, C. (2001) An exploratory study into the effect of exhausting bicycle exercise on endurance and immune responses in post-menopausal women: relationships between vigour and plasma cortisol concentrations and lymphocyte proliferation following exercise. International Journal of Sports Medicine, 22, 447-453. http://dx.doi.org/10.1055/s-2001-16243

[26] Mackinnon, L.T., (1989) Exercise and natural killer cells. What is the relationship? Sports Medicine, 7, 141-149. http://dx.doi.org/10.2165/00007256-198907030-00001

[27] Pedersen, B.K., Tvede, N., Christensen, L.D., Klarlund, K., Kragbak, S. and Halkjr-Kristensen, J. (1989) Natural killer cell activity in peripheral blood of highly trained and untrained persons. International Journal of Sports Medicine, 10, 129-131. http://dx.doi.org/10.1055/s-2007-1024888

[28] Nieman, D.C., Miller, A.R., Henson, D.A., Warren, B.J., Gusewitch, G., Johnson, R.L., Davis, J.M., Butterworth, D.E. and Nehlsen-Cannarella, S.L. (1993) Effects of high- vs moderate-intensity exercise on natural killer cell activity. Medicine \& Science in Sports \& Exercise, 25, 1126-1134. http://dx.doi.org/10.1249/00005768-199310000-00008

[29] Palmø, J., Asp, S., Daugaard, J.R., Richter, E.A., Klokker, M. and Pedersen, B.K. (1995) Effect of eccentric exercise on natural killer cell activity. Journal of Applied Physiology, 78, 1442-1446.

[30] Nielsen, H.B., Secher, N.H., Kappel, M., Hanel, M.B. and Pedersen, B.K. (1996) Lymphocyte, NK and LAK Cell Responses to Maximal Exercise. International Journal of Sports Medicine, 17, 60-65. http://dx.doi.org/10.1055/s-2007-972809

[31] Shephard, R.J. and Shek, P.N. (1999) Effects of exercise and training on natural killer cell counts and cytolytic activity. Sports Medicine, 28, 177-195. http://dx.doi.org/10.2165/00007256-199928030-00003

[32] Fairey, A.S., Courneya, K.S., Field, C.J., Bell, G.J., Jones, L.W. and Mackey, J.R. (2005) Randomized controlled trial of exercise and blood immune function in postmenopausal breast cancer survivors. Journal of Applied Physiology, 98, 1534-1540. http://dx.doi.org/10.1152/japplphysiol.00566.2004

[33] Campbell, P.T., Wener, M.H., Sorensen, B., Wood, B., Chen-Levy, Z., Potter, J.D., McTiernan, A. and Ulrich, C.M. (2008) Effect of exercise on in vitro immune function: A 12-month randomized, controlled trial among postmenopausal women. Journal of Applied Physiology, 104, 1648-1655. http://dx.doi.org/10.1152/japplphysiol.01349.2007

[34] Gleeson, M., McDonald, W.A., Cripps, A.W., Pyne, D.B., Clancy, R.L. and Fricker, P.A. (1995) The effect on immunity of long-term intensive training in elite swimmers. Clinical \& Experimental Immunology, 102, 210-216. http://dx.doi.org/10.1111/j.1365-2249.1995.tb06658.x

[35] Suzui, M., Kawai, T., Kimura, H., Takeda, K., Yagita, H., Okumura, K., Shek, P.N. and Shephard, R.J. (2004) Natural killer cell lytic activity andCD56 $6^{\mathrm{dim}}$ andCD56 $6^{\text {bright }}$ cell distributions during and after intensive training. Journal of Applied Physiology, 96, 2167-2173. 
http://dx.doi.org/10.1152/japplphysiol.00513.2003

[36] Jonsdottir, I.H., Hellstrand, K., Thoren, P. and Hoffmann, P. (2000) Enhancement of natural immunity seen after voluntary exercise in rats. Role of central opioid receptors. Life Sciences, 66, 1231-1239. http://dx.doi.org/10.1016/S0024-3205(00)00428-8

[37] MacNeil, B. and Hoffman-Goetz, L. (1993) Chronic exercise enhances in vivo and in vitro cytotoxic mechanisms of natural immunity in mice. Journal of Applied Physiology, 74, 388-395.

[38] Jadeski, L. and Hoffman-Goetz, L. (1996) Exercise and in vivo natural cytotoxicity against tumour cells of varying metastatic capacity. Clinical \& Experimental Metastasis, 14, 138-144. http://dx.doi.org/10.1007/BF00121210

[39] Timmons, B.W. and Cieslak, T. (2008) Human natural killer cell subsets and acute exercise: A brief review. Exercise Immunology Review, 14, 8-23.

[40] Hoffman-Goetz, L. (1998) Influence of physical activity and exercise on innate immunity. Nutrition Reviews, 56, S126-S130. http://dx.doi.org/10.1111/j.1753-4887.1998.tb01629.x

[41] Gannon, G., Shek. P.N. and Shephard, R.J. (1995) Natural killer cells: Modulation by intensity and duration of exercise. Exercise Immunology Review, 1, 26-48.

[42] Woods. J.A., Evans, J.K., Wolters, B.W., Ceddia, M.A. and McAuley, E. (1998) Effects of maximal exercise on natural killer (NK) cell cytotoxicity and responsiveness to interferon alpha in the young and old. The Journals of Gerontology, Series A: Biological Sciences and Medical Sciences, 53, B430-B437. http://dx.doi.org/10.1093/gerona/53A.6.B430

[43] Gleeson, M. and Bishop, N.C. (2005) The T cell and NK cell immune response to exercise. Annals of Transplantation, 10, 43-48.

[44] Suzui, M., Takeda, K., Yagita, H., Okumura, K., Shek, P.N. and Shephard, R.J. (2005) Changes in the proportion of CD56dim and CD56 $6^{\text {bright }}$ natural killer cells during incremental exercise. Medicine \& Science in Sports \& Exercise, 37, S373. http://dx.doi.org/10.1097/00005768-200505001-01940

[45] Suzui, M., Takeda, K., Yagita, H., Okumura, K., Shek, P.N. and Shephard, R.J. (2006) Changes in the proportions of CD56 $6^{\mathrm{dim}}$ and CD56 ${ }^{\text {bright }}$ natural killer cells during and after acute exercise. Medicine \& Science in Sports \& Exercise, 38, S413.

[46] Nieman, D.C. (1997) Immune response to heavy exertion. Journal of Applied Physiology, 82, 1385-1394.

[47] Nielsen, H.B. and Pedersen, B.K. (1997) Lymphocyte proliferation in response to exercise. European Journal of Applied Physiology and Occupational Physiology, 75, 375-379. http://dx.doi.org/10.1007/s004210050175

[48] Gannon, G.A., Rhind, S.G., Suzui, M., Zamecnik, J., Sabiston, B.H., Shek, P.N. and Shephard, R.J. (1998) Beta-endorphin and natural killer cell cytolytic activity during pro- longed exercise. Is there a connection? American Journal of Physiology, 275, R1725-R1734.

[49] Klokker, M., Kjaer, M., Secher, N.H., Hanel, B., Worm, L., Kappel, M. and Pedersen, B.K. (1995) Natural killer cell response to exercise in humans: Effect of hypoxia and epidural anesthesia. Journal of Applied Physiology, 78, 709-716.

[50] Kotani, T., Aratake, Y., Ishiguro, R., Yamamoto, I., Uemura, Y., Tamura, K. and Ohtaki, S. (1997) Influence of physical exercise on large granular lymphocytes, Leu-7 bearing mononuclear cells and natural killer activity in peripheral blood-NK-cell and NK-activity after physical exercise. Nihon Ketsueki Gakkai Zasshi, 50, 1210-1216.

[51] Del Giacco, S., Tocco, F., Melis, F., Crisafulli, A., Gessa, M., Santoboni, U., Del Giacco, S.G. and Concu, A. (2004) Responsiveness of human natural killer cells during acute, incremental exercise up to exhaustion. Sport Sciences for Health, 1, 36-40. http://dx.doi.org/10.1007/s11332-004-0008-6

[52] Crisafulli, A., Pittau, G.L., Lorrai, L., Carcassi, A.M., Cominu, M., Tocco, F., Melis, F. and Concu, A. (2006) Poor reliability of heart rate monitoring to assess oxygen consumption during field training. International Journal of Sports Medicine, 27, 55-59.

http://dx.doi.org/10.1055/s-2005-837504

[53] Northoff, H., Enkel, S. and Weinstock, C. (1995) Exercise, injury, and immune function. Exercise Immunology Review, 1, 1-25.

[54] Ihara, H., Shino, Y., Morita, Y., Kawaguchi, E., Ashizume, N. and Yoshida, M. (2001) Is skeletal muscle damaged by the oxidative stress following anaerobic exercise? Journal of Clinical Laboratory Analysis, 15, 239-243. http://dx.doi.org/10.1002/jcla.1034

[55] Klapcinska, B., Iskra, J., Poprzecki, S. and Grzesiok, K. (2001) The effects of sprint (300 m) running on plasma lactate, uric acid, creatine kinase and lactate deydrogenase in competitive and untrained men. Journal of Sports Medicine and Physical Fitness, 41, 306-311.

[56] De Vries, W.R., Bernards, N.T., De Rooij, M.H. and Koppeschaar, H.P. (2000) Dynamic exercise discloses different time-related responses in stress hormones. Psychsomatic Medicine, 62, 866-872.

[57] Bagby, G.J., Crouch, L.D. and Shepherd, R.E. (1996) Exercise and cytochines: Spontaneous and elicited responses. In: Hoffman-Gortz, L. and Boca Raton, F.L., Eds., Exercise and Immune Function, CRC press, New York, 55-77.

[58] Gallant, S.P., Underwood, S., Durisetti, L. and Insel, P.A. (1978) Characterization and high affinity of $\beta_{2}$-adrenergic receptor binding by $(-)-\left[{ }^{3} \mathrm{H}\right]$-dihydroprenolol binding to human polymorphonuclear particles. Journal of Clinical Laboratory Analysis, 92, 613-618.

[59] Kappel, M., Tvede, H., Galbo, P., Haahr, P.M., Kjaer, M., Linstow, M., Klarlund, K. and Pedersen, B.K. (1991) Evidence that the effect of physical exercise on NK cell activity is mediated by epinephrine. Journal of Applied Physiology, 70, 2530-2534.

[60] Klokker, M., Secher, N.H., Madsen, P. and Pedersen, B.K. (1997) Adrenergic $\beta_{1^{-}}$and $\beta_{1+2}$-receptor blockade suppress the natural killer cell response to head-up tilt in humans. Journal of Applied Physiology, 83, 1492-1498.

[61] Gabriel, H.H. and Kindermann, W. (1998) Adhesion molecules during immune response to exercise. Canadian Journal of Physiology Pharmacology, 76, 512-523. 
http://dx.doi.org/10.1139/y98-067

[62] Nagao, F., Suzui, M., Takeda, K., Yagita, H. and Okumura, K. (2000) Mobilization of NK cells by exercise: Downmodulation of adhesion molecules on NK cells by cathecolamines. American Journal of Physiology. Regulatory Integrative and Comparative Physiology, 279, R1251-R1256.

[63] Nomoto, Y., Karasawa, S. and Uehara, K. (1994) Effects of hydrocortisone and adrenaline on natural killer cell activity. British Journal of Anaesthesia, 73, 318-321. http://dx.doi.org/10.1093/bja/73.3.318

[64] Shakhar, G. and Ben-Eliyahu, S. (1998) In vivo beta-adrenergic stimulation suppresses natural killer activity and compromises resistance to tumor metastasis in rats. Journal of Immunology, 160, 3251-3258.

[65] Knudsen, J.H., Kjaersgaard, E., Jensen, E.W. and Christensen, N.J. (1994) Percentage of NK-cells in peripheral blood in resting normal subjects is negatively correlated to plasma adrenaline. Scandinavian Journal of Clinical \& Laboratory Investigation, 54, 221-225. http://dx.doi.org/10.3109/00365519409088428

[66] Nieman, D.C., Nehlsen-Cannarella, S.L., Donohue, K.M., Chritton, D.B., Haddock, B.L., Stout, R.W. and Lee, J.W. (1991) The effects of acute moderate exercise on leuchocyte and lymphocyte subpopulations. Medicine \& Science in Sports \& Exercise, 23, 578-585. http://dx.doi.org/10.1249/00005768-199105000-00010

[67] Field, C.J., Gougeon, R. and Marliss, E.B. (1991) Circulating mononuclear cell numbers and function during intense exercise and recovery. Journal of Applied Physiology, 71, 1089-1097.

[68] Harizi, H. (2013) Reciprocal crosstalk between dendritic cells and natural killer cells under the effects of PGE2 in immunity and immunopathology. Cellular \& Molecular Immunology, 10, 213-221. http://dx.doi.org/10.1038/cmi.2013.1

[69] Holt, D.H., Ma, X., Kundu, N., Collin, P.D. and Fulton, A.M. (2012) Modulation of host natural killer cell functions in breast cancer via prostaglandin E2 receptors EP2 and EP4. Journal of Immunotherapy, 35, 179-188. http://dx.doi.org/10.1097/CJI.0b013e318247a5e9

[70] Zeddou, M., Greimers, R., de Valensart, N., Nayjib, B., Tasken, K., Boniver, J., Moutschen, M. and Rahmouni, S. (2005) Prostaglandin $E_{2}$ induces the expression of functional inhibitory CD94/NKG2A receptors in human $\mathrm{CD}^{+}$ $\mathrm{T}$ lymphocytes by a cAMP-dependent protein kinase A type I pathway. Biochemical Pharmacology, 70, 714-724. http://dx.doi.org/10.1016/j.bcp.2005.05.015

[71] Uchida, M.C., Nosaka, K., Ugrinowitsch, C., Yamashita, A., Martins, Jr. E., Moriscot, A.S. and Aoki, M.S. (2009) Effect of bench press exercise intensity on muscle soreness and inflammatory mediators. Journal of Sports Sciences, 27, 499-507. http://dx.doi.org/10.1080/02640410802632144

[72] Gatti, C., Cavallo, R., Sartori, M.L., Del Ponte, D., Masera, R., Salvadori, A., Carignola, R. and Angeli, A. (1987) Inhibition by cortisol of human natural killer (NK) cell activity. Journal of Steroid Biochemistry, 26, 49-58. http://dx.doi.org/10.1016/0022-4731(87)90030-6

[73] Singh, A., Zelazowska, E.B., Petrides, J.S., Raybourne,
R.B., Sternberg, E.M., Gold, P.W. and Deuster, P.A. (1996) Lymphocyte subset responses to exercise and glucocorticoid suppression in healthy men. Medicine \& Science in Sports \& Exercise, 28, 822-828. http://dx.doi.org/10.1097/00005768-199607000-00008

[74] Wrona, D., Trojniar, W., Borman, A., Ciepielewski, Z. and Tokarski, J. (2001) Stress-induced changes in peripheral natural killer cell cytotoxicity in pigs may not depend on plasma cortisol. Brain, Behavior, and Immunity, 15, 5464. http://dx.doi.org/10.1006/brbi.2000.0583

[75] Luger, A., Watschinger, B., Deuster, P., Svoboda, T., Clodi, M. and Chrousos, G.P. (1992) Plasma growth hormone and prolactin responses to graded levels of acute and to a lactate infusion. Neuroendocrinology, 56, 112-117. http://dx.doi.org/10.1159/000126912

[76] De Meirleir, K.L., Baeyens, L., L'Hermite-Baleriaux, M. and Hollman, W. (1985) Exercise-induced prolactin release is related to anaerobiosis. Journal of Clinical Endicrinology Metabolism, 60, 1250-1252. http://dx.doi.org/10.1210/jcem-60-6-1250

[77] Melis, F., Crisafulli, A., Rocchitta, A., Tocco, F. and Concu, A. (2003) Does reduction of blood prolactin levels indicate high activity of dopaminergic systems deputated to rewarding in top athletes? Medical Hypotheses, 61, 133135. http://dx.doi.org/10.1016/S0306-9877(03)00146-4

[78] Chambers, W.H., Amscato, A.A., Smith, M.S., Kenniston, T.W., Herberman, R.B. and Appasamy, P.M. (1995) Prolactin receptor expression by rat NK cells. Natural Immunity, 14, 145-156.

[79] Vidaller, A., Guadarrama, F., Llorente, L., Mendez, J.B., Larrea, F., Villa, A.R. and Alarcon-Segovia, D. (1992) Hyperprolactinemia inhibits natural killer (NK) cell function in Vivo and its bromocriptine treatment not only corrects it but makes it more efficient. Journal of Clinical Immunology, 12, 210-215. http://dx.doi.org/10.1007/BF00918091

[80] Shinkai, S., Shore, S., Shek, P.N. and Shephard, R.J. (1992) Acute exercise and immune function-Relationship between lymphocyte activity and changes in subset counts. International Journal of Sports Medicine, 13, 452-461. http://dx.doi.org/10.1055/s-2007-1021297

[81] Tvede, N., Kappel, M., Halkjoer-Kristensen, J., Galbo, H. and Pedersen, B.K. (1993) The effect of light, moderate and severe bicycle exercise on lymphocyte subsets, natural and lymphokine activated killer cells, lymphocyte proliferative response and interleukin 2 production. International Journal of Sports Medicine, 14, 275-282. http://dx.doi.org/10.1055/s-2007-1021177

[82] Shek, P.N., Sabiston, B.H., Buguet, A. and Radomski, M.W. (1995) Strenuous exercise and immunological changes: A multiple-time-point analysis of leuchcyte subsets, CD4/CD8 ratio, immunoglobulin production and NK cell response. International Journal of Sports Medicine, 16, 466-474. http://dx.doi.org/10.1055/s-2007-973039

[83] Shephard, R.J. and Shek, P.N. (1999) Effects of exercise and training on natural killer cell counts and cytolytic activity. Sports Medicine, 28, 177-195. http://dx.doi.org/10.2165/00007256-199928030-00003

[84] Roecker, K., Mayer, F., Striegel, H. and Dickhuth, H.H. 
(2000) Increase characteristics of the cumulated excess$\mathrm{CO}_{2}$ and the lactate concentration during exercise. International Journal of Sports Medicine, 21, 419-423. http://dx.doi.org/10.1055/s-2000-3836

[85] Kruijsen-Jaarsma, M., Révész, D., Bierings, B., Buffart, L.M. and Takken, T. (2013) Effects of exercise on immune function in patients with cancer: A systematic review. Exercise Immunology Review, 19, 120-143.
[86] Inbar, S., Neeman, E., Avraham, R., Benish, M., Rosenne, E. and Ben-Eliyahu, S. (2011) Do stress responses promote leukemia progression? An animal study suggesting a role for epinephrine and prostaglandin-E2 through reduced NK activity. PLoS ONE, 6, Article ID: E19246. http://www.ncbi. nlm.nih.gov/pmc/articles/ MC3084788/ http://dx.doi.org/10.1371/journal.pone.0019246. 